\title{
Asian Countries Response and Management against the COVID-19 Pandemic
}

Shipra Agarwal ${ }^{1}$

\begin{abstract}
$\underline{\text { Abstract }}$
COVID-19 is a disease caused by the novel coronavirus. This is the virus firstly reported in the end of 2019 and World Health Organization already had declared COVID-19 a pandemic "an international emergency as the disease is spreading at alarming levels all over the world". COVID-19 has affected more than people around the world and people in Asia. The governments of various countries took emergency measures and effective strategies to contain the spread of virus and protect the public. Restrictive measures like social distancing, lockdown, case identification, isolation, contact tracing, and quarantine of exposed people were revealed to the most efficient actions to control the disease spreading. However, countries had different response and outcomes. Many countries bordering China which is the epicentre of Covid-19 have very few cases; some countries such as Singapore, Thailand, Vietnam, South Korea, Japan, etc. had the best response for controlling the situation however some are not performing well. So in this article, we present on an overview of the presently obtainable information on the strategies, and management of this novel coronavirus. This review will help the readers to understand the difference in response by different countries and their outcomes. This may suggest the future directions that the global community should take to manage and mitigate the emergency.
\end{abstract}

\section{Southeast Asia}

\section{Brunei}

Brunei is the smallest country has a population of 4.2 lakhs only. It has a low population density and good health indicators. On January $30^{\text {th }}, 2020$, the Brunei government announced denied entry for travellers who had been in China 14 days back, to limit the spread of the COVID 19. In the mid of February, the Brunei government also extended the restrictions of some provinces of China before its first case. On March 9, 2020, Brunei's Ministry of Health announced the first case of COVID-19, it has currently 138 cases and the cases were linked back to a large-scale religious event in Malaysia at the end of February. It had a new case of Covid-19 on March $18^{\text {th }}$. It restricted movements early on closed borders with Malaysia. Since $23^{\text {rd }}$ March the government imposed restrictions including banning foreign visitors, prohibiting mass gatherings, and restricting religious-related activities. Moreover, it imposed strict quarantine or lockdown rules for the next 10 days. It conducted extensive testing and tracking those under home quarantine and recovered by Covid-19. The government announced jail for prohibition of the orders up to six months and fine up to $\$$ 10,000. On April 13, The government further had announced economic measures to assist health care workers, including doctors, nurses, volunteers, hospital cleaners, and security guards by giving them an allowance of $\$ 400$ per month.

\footnotetext{
${ }^{1}$ Shipra Agarwal is a Research associate of a Think Tank, Sanrachna.
} 


\section{Cambodia}

Cambodia which is sharing a border with China has a population of $16,249,798$. It is a rural populated country and its health outcomes are worst among Southeast Asian countries. It had its first case of COVID-19 reported on January 27, 2020. Currently it has fewer cases just 122 as earlier Cambodia used its rapid nucleic acid amplification tests technology that is a quick testing technology that gives results in less than two hours, developed by a team of researchers at the University of Hong Kong in January. In Cambodia, on $17^{\text {th }}$ March, it banned foreign travel on arrivals from European countries, the US, and Iran as most of the cases was found from these countries. On $31^{\text {st }}$ March, after declaring the emergency, suspended all visas till April $30^{\text {th }}$, banned entries, closed borders and imposed mandatory quarantine for 14 days from $8^{\text {th }}$ April to all the travellers. The country is allocating more economic resources to the health sector amid concerns about the country's health system and its ability to handle rising cases.

\section{Indonesia}

Indonesia has the population to about 267,663,435 i.e. largest in south Asia and four largest in the world. On March 2, 2020, Indonesia reported its first cases of COVID-19. It has a high elderly population and health outcomes are also not well. It currently has 9096 cases. On $31^{\text {st }}$ March, the country declared a public health emergency and it imposed some restrictions by banning foreign travel, and closing land borders and land ports with Timor-Leste and Papua. The Indonesian government had announced lockdown in Jakarta (the epicentre of COVID-29 outbreak) after the rapid spread of the COVID-19 in the country and other metropolitan areas. Indonesia has the highest number of deaths as on the $28^{\text {th }}$ of April and around 2200 people were died due to symptomatic conditions like Covid-19 which were unreported in the provinces. The government banned tens of millions of people returning to their home province at the end of Ramadan. However, it was weak in communicating public awareness to social distance and did not enforce the selfquarantine. The assistance was taken by the Chinese institutions and ministries which sent 40 tons of Covid19 test kits and other medical supplies to Indonesia to complete at least 10,000 tests per day.

\section{Laos}

Laos is the most rural country in Southeast Asia has 7,061,567 populations. It has bad health outcomes. Laos announced its first two COVID-19 confirmed cases on March 24. Currently it has only 19 cases, the lowest of all Southeast Asian countries. From $30^{\text {th }}$ March, it had sealed its international borders with China and Myanmar and entry bans till the $3^{\text {rd }}$ of May. The citizens returning Laos were under a mandatory quarantine of 14 days which were officially monitored. It had also issued lockdown (restricted social gatherings and enforced stay at home) for all the citizens and closed the provincial borders for a month. Laos has currently recorded just a dozen of cases to about 19 even the country's has almost a non-existent health care system. However, it has received assistance from China in early March. Further, along with all non-essential services, on $15^{\text {th }}$ April, the government has ordered all the private hospitals and clinics to be closed till $3^{\text {rd }}$ May. 


\section{Malaysia}

Malaysia has a population of $31,528,525$; it has 5820 confirmed cases now. It has one of the best performing health systems and has good health outcomes. It initially had imposed a temporary travel ban on arrivals from all Chinese provinces that have been placed under lockdown by the Chinese government and imposed entry bans. After an initially slow reaction, on $16^{\text {th }}$ March, Malaysia had closed its borders and announced partial lockdown enforced by the army till mid of March. Army personals were ordered for aggressive testing and contact tracing through drones. The government was allowing the citizens to return to Malaysia only if they were tested and placed in quarantine facilities. Malaysia became the first country in the region to announce a lockdown of the country extended to $12^{\text {th }}$ May.

\section{Myanmar}

Myanmar has 53,708,395 population sharing a long border with China has bad health outcomes. It was reported with its first Covid-19 case on $23^{\text {rd }}$ march. It has 146 cases as a reason for the lack of testing. Myanmar On $13^{\text {th }}$ April, it imposed some limited measured on international travel and arrival and closed border or imposed restrictions except for trade. On $19^{\text {th }}$ April, the national government has declared an emergency announced a curfew till $18^{\text {th }}$ June in Yangon's. All the schools nation-wide will be closed until May. Since April $22^{\text {nd }}$, the military has been securing quarantine facilities in main cities and delivering medical supplies to remote regions. Myanmar has an underdeveloped health care system and underreporting of cases due to low testing remains a major concern. Thus, it is working with other governments to increase capacity in areas such as testing in light of the severe constraints of Myanmar's health system. It took external help from China, Singapore, and Japan that revives from the current crisis.

\section{The Philippines}

Philippians has only 7958 cases out of 106,651,922 populations. It has the most urban population and average health outcomes. The Philippines have imposed strong measures like banning foreign nationals coming from China, Hong Kong, and Macau and canceling flights until the end of April. It then imposed the partial lockdown until May 15 and the rest of the country under General Community Quarantine (GCQ) until May 15. The Philippines has among the highest numbers of new confirmed cases per day in the region. The country also announced an economic stimulus package and a social protection program. Further, China sent a team of medical experts and the second batch of medical supply donations to the Philippines on April 5.

\section{Singapore}

Singapore has currently 14,951 cases of 5638,676 populations, density populated, and the fastest aging population and excellent health system and performance. The country had its first case on $23^{\text {rd }}$ January. From the very beginning in January, it banned entry from China and self - developed testing kits 
being a highly technologically advanced country. In early Feb, has contained the virus through its early detection and quick response through widespread testing, contact tracing through an app launched on $20^{\text {th }}$ March. From March-end, it banned all travelers entering Singapore and announced a mandatory quarantine for Covid-19 positive cases and their contact persons. At the beginning of the month April, it imposed quarantine for all the 20,000 manual migrant workers which are of the deprived community. Singapore was the first Southeast Asian country with excess capacity of testing kits and it has tested more than 24000 per million populations. The government takes care of the cost of hospitalization of patients, irrespective of whether the patient is from Singapore or abroad. It has the best communication channel where health authorities provide daily information on mainstream media through Telegram and WhatsApp groups set up with doctors in the public and private sectors where more detailed clinical and logistics information is shared.

Singapore is known for its world-class health system. However, Singapore has the highest number of cases across South Asia that came in mid-April. It was due to migrant workers living in crowded dormitories with shared kitchens and bathrooms as over half of the cases reported in the location of migrant workers as they were not a part of nationwide mask distribution in February. Thus, for strict compliances to control the spread, from $21^{\text {st }}$ April, it announced stay at home till may end and banned social gatherings till the beginning of May. To balance the normality with compliance from residents, the regulations are applicable till the next 6 months and those who offend the rules and regulations will be in jail for six months with a fine of $\$ 7000$.

\section{Thailand}

Thailand has 69,428,524 people and 2938 Covid-19 cases. The first case outside of China was reported in Thailand on 13 January 2020. It initially in early February has issued a travel advisory urging citizens to avoid non-essential travel to China. On $22^{\text {nd }}$ March, banned all foreign visitors and closed borders by further imposing a partial curfew. Then after a month, the government announced a strict measure on migrant workers till $30^{\text {th }}$ November to stay in Thailand only. It banned the flights till the end of May. On April 3 prohibiting people from leaving their houses from 10 p.m. to 4 a.m., with exemptions for essential services till may end. The army is helping enforce the curfew, and violators risk a $\$ 1,200$ fine (40,000 baht). On $15^{\text {th }}$ April, declining in the cases was observed so it reopened some business operations. Thailand had enacted extensive surveillance, monitoring, contact tracing, and isolation of those infected or in contact with the disease. The government has also passed three stimulus packages covering a range of areas, including loans, worker aid, and tax benefits. Inconsistent policies about travel and quarantine, poor communication, and supply shortages have highlighted the government's inability to promptly and adequately respond to the surge of Covid-19 cases, resulting in widespread criticism and frustration on social media in Thailand.

\section{Vietnam}


Vietnam has a population of 96 million and does not have good health performance. Vietnam's sharing a border with China has 96 million people and only 270 Covid-19 cases but no deaths. It has imposed early travel restrictions in late January has and 14 days quarantine measures in quarantine camps run by the military during mid-February. Vietnam imposed a lockdown on $1^{\text {st }}$ April and in less than a month the country has lifted it on $23^{\text {rd }}$ April with some restrictions of social distancing, wearing masks and public gatherings of not more than 20 people and as no province was highly prone and no death case was found. The government also mobilized retired doctors and nurses and medical students to support the health system. Despite limited resources Vietnam has managed to contain the pandemic relatively well with its prompt and aggressive response through its monitoring strategies, and communicate effectively with citizens. It banned foreign from affected areas and a new mandatory regulation imposed for incoming travelers to Vietnam has to be quarantined at centralized facilities for 14 days. Violators may be fined between $\$ 426$ and \$853 (VND 10-20 million) (Nguyen,2020 ${ }^{\mathrm{i}}$ ). In Vietnam, in the first period the main source of infections was associated with travel from China, then Europe, and then the cases have increased due to the local transmission. The health ministry strategic move was a combination of extensive efforts includes isolating infected people and tracing and quarantining their contacts. In particular, the use of face masks and hand sanitizers has been highly encouraged.

\section{Endnotes}

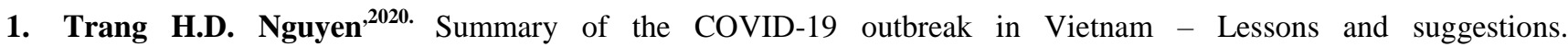
https://www.ncbi.nlm.nih.gov/pmc/articles/PMC7146658/pdf/main.pdf

2. Amy Searight,2020. Strengths and Vulnerabilities in Southeast Asia's response to the Covid-19 Pandemic. https://www.csis.org/analysis/strengths-and-vulnerabilities-southeast-asias-response-covid-19-pandemic

3. Dr. Temjenmeren Ao,2020. Confronting the Threat: ASEAN's Response to COVID-19. Indian Council of World Affairs. https://www.icwa.in/show_content.php?lang=1\&level=3\&ls_id=4689\&lid=3523

4. Prashanth Parameswaran,2020. https://thediplomat.com/2020/04/covid-19-in-asia-a-country-by-country-guide/

5. National Responses to COVID-19 in Southeast Asia. Centre for Strategic and International Studies, 2020. https://www.csis.org/programs/southeast-asia-program/southeast-asia-covid-19-tracker-0. prod.s3.amazonaws.com/s3fs-public/200429_COVID_Tracker.pdf?hL9PQ_S7ZssuVM9oKE5klUU4.6r_si50

6. World Development Indicators, THE WORLD BANKSoutheast Asia

7. Kai Hong

Phua,2011.

https://www.researchgate.net/publication/49787720_Health_in_Southeast_Asia_1_Health_and_health-

care_systems_in_southeast_Asia_diversity_and_transitions

8. Singapore and COVID-19: Strengths, Shifts, and Limits of National Response. https://www.cfr.org/blog/singapore-and-covid-19-strengths-shifts-and-limits-national-response

9. Reported Cases and Deaths by Country, Territory, or conveyance,2020. https://www.worldometers.info/coronavirus/?utm_campaign=homeAdvegas1?/embed/fd0k_hbXWcQ

10. Helena Legido-Quigley,2020. Are high-performing health systems resilient against the COVID-19 epidemic? https://www.thelancet.com/action/showPdf?pii=S0140-6736\%2820\%2930551-1

\section{Central Asia}




\section{Kazakhstan}

Kazakhstan has 18.7 million people and 4753 Covid-19 cases. The country has the largest economy in Central Asia and shares its largest border with China. Just after the WHO declaration of a public health emergency, the country closed its borders and suspended air and train traffic. Before confirming its first case it took measures such as cancellation of the International Women's Day festivities in the interest of public health. Further, just after a case confirmed, it scheduled its big events in late March and even for May. It then took measures like lockdown by closing a non-essential business; banned key food exports to maintain food security, and took quarantine measures till the end of April. The tools like facial cameras to track people's movements are used for those who violate the quarantine rules have been placed in custody.

\section{Kyrgyzstan}

Kyrgyzstan has 6.5 million of population and just 906 Covid-19 confirmed cases till now. As in late January, after the WHO declared a global pandemic, the country closed its border with China. Bishkek the largest city in Kyrgyzstan had begun screening for the citizens arrived from China and quarantined them. Further, in the mid of march after the COVID-19 cases were confirmed in the country, other measures were taken to contain the spread that includes lockdowns, temporary travel ban of foreigners, closure of non- essential business closures, and banned key food exports till the end of April.

\section{Tajikistan}

Tajikistan has a population of 9.5 million and with only 440 cases. It shares a border with China. From the beginning of the disease alert, it closed travel between Tajikistan and China. The country had responded by limiting entry to the country, closing borders, and forcibly quarantining people arriving from abroad mainly China, and raised awareness. The state has also accepted and solicited aid in various forms from the United States, WHO, and its neighboring countries and to spread the information awareness campaigns. However, no closure was ordered by the government.

\section{Turkmenistan}

Turkmenistan has a population of 6 million however it has the unbelievable number of confirmed Covid19 cases that account for no cases. It took basic measures in late January by canceling the flights to and from China. The country to an initiative for human rights, the people who arrived from abroad in the country was isolated and forcibly quarantined in camps. This is the good news about Turkmenistan about the isolation or sealed off the capital (restriction on movement of people and goods) with the best of its situation however the country did not cancel mass gatherings.

\section{Uzbekistan}


Uzbekistan is the highest populated country in Central Asia with a population of 33.4 million with 2314 confirmed Covid-19 cases. It does not share a direct border with China. In early February, it closed its borders, canceled mass events. Just after its very first case of Covid-19 in the mid of March, it declared a public health emergency and took strict action by lockdown and restricted movement within cities and suspended transport. Uzbekistan had also taken all the strict similar emergency measures and extended them to the $10^{\text {th }}$ of May. It ordered penalties on circulating false information of the virus and increased prison sentences from five to a maximum of 10 years in prison. Further, it imposed a fine of more than USD 9,200 or three years' imprisonment.

\section{Endnotes}

1. Human Rights Watch. 2020. Central Asia: Respect Rights in Covid-19 Responses. https://www.hrw.org/news/2020/04/23/central-asia-respect-rights-covid-19-responses.

2. Clement, V., 2020. How Central Asia Copes With COVID-19. Wilson Center. Available at: <https://www.wilsoncenter.org/blog-post/how-central-asia-copes-covid-19>.

3. Worldometers.info. 2020. Coronavirus Update (Live): 4,146,284 Cases and 281,969 Deaths from COVID-19 Virus Pandemic

Worldometer. <https://www.worldometers.info/coronavirus/?nsukey=Z3HCt0uJ\%2FQBWHQWquh8YEiNmpQSwP3MjTX5s6ZoL pNa4vvD\%2Fx2HgoJeT9Z8xXu6cN0yKYRiHWPWJfB6AkLH5FFeotfY1mo0ezbIVe9RxITpzXJme\%2BdREAnAZ IRBBI1eEVar\%2BYuty\%2By9InkUmuFyYEGXryE9c\%2F5aTcB8pLOCE1D4kBhwDxkpe6\%2BsDkQGbq7S9jmQ UZN3qrpIXws58rU5M7g\%3D\%3D>.

4. ReliefWeb. 2020. How Central Asia Copes With COVID-19 - Tajikistan. <https://reliefweb.int/report/tajikistan/howcentral-asia-copes-covid-19>.

5. Zafar, D., 2020. Varied Response In The Central Asian Republics To The Coronavirus Pandemic - Indian Council Of World Affairs (Government Of India). $<$ https://www.icwa.in/show_content.php?lang=1\&level=3\&ls_id=4686\&lid=3521>.

6. Tiezzi, S., Putz, C., and Panda, A., 2020. COVID-19 in Asia: A Country-By-Country Guide. Thediplomat.com. $<$ https://thediplomat.com/2020/04/covid-19-in-asia-a-country-by-country-guide/>.

7. Worldometers. (Coronavirus Update (Live): 5,481,115 Cases and 346,071 Deaths from COVID-19 Virus Pandemic Worldometer [Internet]. Worldometers.info. $2020 \quad\left[10^{\text {th }}\right.$ May 2020]. Available from: https://www.worldometers.info/coronavirus/.

\section{$\underline{\text { East Asia }}$}

\section{China}

Wuhan in China which is the epicenter of the Covid-19 virus had moved swiftly to prevent the spread. Followed by the announcement of an emergency, it had constructed new hospitals in late January. China took strict decisions to stop the spread of the disease using digital surveillance for Covid-19 tracking. China used a combination of high tech- scanning of its population through contact tracing, using AI-based contactless temperature detection software and facial recognition technology and automated vehicle, and $5 \mathrm{G}$ technology in Wuhan was used for telemedical care for highly infected areas. During the early days of March, there were affected people arriving from overseas to Beijing, thus China banned entry from overseas flights to Beijing and canceled the flights and made some hospitals as specialized hospitals for 
affected people. China's strong governance was to strictly restrict community transmission by maintaining the entry and exit in all areas.

\section{Japan}

Japan had its first case in mid of January and it had very few cases after a month as it managed to avoid the infection. It restricted entry of visitors from Hubei to the country and later imposed a travel ban on many countries. Japan was then shifted its focus from containment to prevention and treatment and started extensive contact tracing to find the new clusters. Further, the country provided medical care for ill patients to avoid the burden of health infrastructure. Since the beginning of March, the cases in the two cities; Tokyo and Osaka had a slightly increasing number of cases as Japan did not adopt extensive testing. The country did not impose strict lockdown however; Japan's government approach was to work on strengthening the medical system as they had enough time and resources to respond to the situation. The country's early actions such as avoiding large public gatherings, postponed the Olympics, border control, promoting telework at home made it possible.

\section{South Korea}

South Korea had its first case in mid of January. It restricted travel entry from Wuhan and very early it implemented screening at all ports for those who entered Korea. The country managed its spike in the cases during the mid of February. However, just a month after; the cases were brought down to half. It has 51.2 million and currently it has 10,874 cases. A combination of extensive testing possibly highest in the world, location tracking, and contact tracing helped the country to identify cluster infections and get control of the virus. The experience of the MERS outbreak forced Korea to use its advanced biotechnology, and the country scaled up its production of kits very early. It provided free tests for its citizens and provided drive through testing, mobile facilities, and door to door service. Its high tech tracking ability and surveillance system enabled it to people at high risk and contact persons with the infected one using CCTV records, credit cards, and mobile data. Self-quarantine Safety Protection is a mobile app used to trace citizens on lockdown where a person can be traced everywhere. It had also proved to be successful in responding to COVID - 19 through disclosing accurate information transparently with the voluntary participation of citizens without protest.

\section{Taiwan}

Taiwan has a cross border connection with China. Despite this it had managed to keep itself out of the virus as it has very few cases till the mid of April. And most of the cases do not indicate community transmission. Taiwan announced medical advisory very early as on $31^{\text {st }}$ December to bound visitors from Wuhan with 14- days self -vigilance, wearing masks, and temperature check and medical test. The government implemented travel restrictions and banned flights from Wuhan on $23^{\text {rd }}$ January just after its first case reported on $21^{\text {st }}$ January. In addition to preventing panic buying the government distributed masks through the national insurance card system and made a provision of free treatment for those who are not insured and allowance for medical staff. From the end of January, it used its technology for 
surveillance by monitoring through mobile phone and strengthens case identification through rolling out testing, quarantined the suspicious cases by providing passengers with the health declaration pass vis SMS that had given access to patients to all hospitals, clinics, and pharmacies to know the status of the patients. Further, the government increased the production of medical supplies by resource allocation and ensured the availability of PPE by banning exports. Later on, in mid of March it banned the entry of all foreign nationals to control the virus. This is how it controlled the spread with the early response; mitigation is the key to controlling it.

\section{Hong Kong}

In late January, Hong Kong declared the emergency of the Covid-19 epidemic and managed to control the spike in cases. The population used their previous lessons from SARS and reverted to mask-wearing and social distancing protocols. Hong Kong has achieved impressive results as a reason for effective policy decisions informed by healthcare experts working on infectious diseases. It responded early on the closing of borders to visitors and non- residents, banning of large public gatherings, many businesses and public sector workers are working from home through strict protocols in place on distancing between people. Contact tracing through advanced electronic wristbands connected to mobile technology has been used and distributed to the arrivals to ensure the action and measures a person is taking care of.

\section{Mongolia}

Mongolia is a country with just 3.2 million populations. The country has another success story for COVID-19 as it has controlled its cases and so far Mongolia had reported the lowest number of infected cases just 42 cases of COVID-19 with no death in East Asia. The government response to the virus was early preventive measures by the mid of February by shutting its extensive border with China and Russia further banned international flights from South Korea. Its first case came at the beginning of March and magnolia has a weak health system. However, so far, government enforcement strategy and public support seems to have worked such as wearing masks in public and implemented C \$75 fines for breaking the rule, canceled mass gatherings and large events, closure of transportation system in the capital city and compulsory isolations in hospitals for the arrivals for 14 days extended for a maximum of 21 days. Its aggressive contact tracing and testing have been conducted in hospitals to have immediate isolation for those with symptoms of COVID -19.

\section{Endnotes}

1. John, D., 2020. COVID-19 Situation in East Asia: A Comparative Perspective - Indian Council of World Affairs (Government of India). [online] Icwa.in. Available <https://www.icwa.in/show_content.php?lang=1\&level=3\&ls_id=4678\&lid=3518> [Accessed 15 May 2020]. 
2.

Lkhaajav B. Mongolia's Small-Country Strategy for Containing COVID-19 [Internet]. Thediplomat.com. 2020 [cited 18 May 2020]. Available from: https://thediplomat.com/2020/03/mongolias-small-country-strategy-for-containingcovid-19/

3. Shaw R, Kim Y, Hua J. Governance, technology and citizen behavior in a pandemic: Lessons from COVID-19 in East Asia. Progress in Disaster Science [Internet]. 2020;6:100090. Available from: http://Governance, technology and citizen behavior in a pandemic: Lessons from COVID-19 in East Asia

4. TSANG C, MULTAN WU A. Asian responses to COVID-19 - Policy Forum [Internet]. Policy Forum. 2020 [cited 18 May 2020]. Available from: https://www.policyforum.net/asian-responses-to-covid-19/

5. Tiezzi, S., Putz, C., and Panda, A., 2020. COVID-19 In Asia: A Country-By-Country Guide. [online] Thediplomat.com. Available at: <https://thediplomat.com/2020/04/covid-19-in-asia-a-country-by-country-guide/> [Accessed 13 May 2020].

6. Jargalsaikhan M. Mongolia's Effective ‘Analogue' Approach to COVID-19 Containment [Internet]. Asia Pacific Foundation of Canada. 2020 [cited 18 May 2020]. Available from: https://www.asiapacific.ca/publication/mongolias-effective-analogueapproach-covid-19-containment

7. Worldometers. (Coronavirus Update (Live): 5,481,115 Cases and 346,071 Deaths from COVID-19 Virus Pandemic Worldometer [Internet]. Worldometers.info. $2020 \quad\left[10^{\text {th }} \quad\right.$ May 2020$]$ Available from: https://www.worldometers.info/coronavirus/)

\section{$\underline{\text { South Asia }}$}

\section{Bangladesh}

Bangladesh has a population of 164 million and it had more than 14000 cases and 228 deaths as of 10th May. The Bangladeshi government has treated the pandemic seriously and taken earlier steps by reducing international flights and imposed thermal scanner checking of international travelers and sailors of freight ships. Since mid of March, the government imposed a 14-day obligatory quarantine for all travelers entering the country. However, the lack of quarantine facilities resulted in unrestrictive movements and a lack of testing. Later at the end of March it then imposed nationwide lockdown that had been extended to May.

\section{India}

India has a vast population with 1380 million populations. Early on, the Indian central government treated the pandemic with seriousness by banning overseas arrivals by flights to the country and later on at the end of March has ordered a nationwide lockdown. India's proactive approaches to limit the spread were to create public awareness, strengthen testing facilities, enhancing medical infrastructure and supplies. Contact tracing has been done through an app Aarogya Setu advised by the government. Along with social distancing, quarantine measure is taken for those with Covid-19 symptoms. However, India as at the beginning of May had more than 65000 confirmed cases that have now grown to 1, 00,000 as a result of the large population, breaking of rules that lead to community transmission, non-extensive testing, and lack of public support. However, being a diverse country its regional results have varied like Kerala had given a robust response to the pandemic by rapid testing of COVID-19 with the idea of identifying cases of community transmission and determining the extent of herd immunity in the population. 


\section{The Maldives}

The Maldives is a tiny Island state also fighting the pandemic of Covid-19. The first infection identified was in early March and currently it has 835 positive cases as on $10^{\text {th }}$ May with only 3 deaths. The country holds to have few cases as a result of taking steps since January 2020 to counter the growing pandemic. Despite more than 1 million arrivals a year, it canceled the travel visas on arrivals to restrict international arrivals, created quarantine facilities. The government ordered lockdown which has been extended till May. Traveling between the islands is also suspended.

\section{Nepal}

Nepal shares a border with India and China. It has become a second less infected country with very few cases accounts for 110 in 29.1 million populations. Nepal's first confirmed case was in January. It then suspended International flights to Nepal for the citizens till the end of May. Even in Nepal the death toll is zero due to Covid-19 while the number of positive cases was 101 as on the $10^{\text {th }}$ of May. Even then Nepal went for an extended week-long lockdown from March 24, 2020 that has again been extended till $2^{\text {nd }}$ June.

\section{Pakistan}

Pakistan is the second-highest populated country in South Asia after India with a population of 220 million. Pakistan facing the Covid-19 pandemic and it had nearly 30,000 cases and 639 deaths as on $10^{\text {th }}$ May. Pakistan had its very first case on ..... Its initial response was to restrict the travel and advised quarantine and self-isolation measures as the complete lockdown was not possible due to extreme poverty. The Health ministry introduced screening at airports in late January. However later in mid of March social distancing and public gatherings were issued and before that at the beginning of April, there was a spike in the spread of the virus. Consequently several shutdowns as various levels have been imposed all over Pakistan which is not so impactful. Pakistan's testing capacity has improved and contact tracing is done through mobile tracking.

\section{Sri Lanka}

Srilanka on the edge of India is doing the best among all south Asian countries. It has a population of 21 million. The country reported its first case on $27^{\text {th }}$ January and now with 855 Covid-19 confirmed cases as of 10th May. The country has contained the spread through social distancing as an initial advisory mid of January. Its first case came after a week and screening of travelers began on the same day. At the beginning of March, the travelers coming from Italy, South Korea, and Iran were quarantined for 2 weeks. Later the country suspended visas on arrival and advised work from home. Further Srilanka has the highest testing rate across South Asia. 


\section{Afghanistan}

Afghanistan has 38 million populations; it shares a porous border with India. The country was at the utmost risk of Covid-19. Initially the government imposed partial lockdown in 3 provinces namely Herat, Nimroz, and Farah. Further the government advised social distancing, banned large public gatherings, and implemented quarantine. The lockdown further expanded to other provinces. However, currently, as of $10^{\text {th }}$ May, it has 3563 cases and 106 deaths. The country has low testing capacity due to a few laboratories that are well equipped for testing.

\section{Bhutan}

Bhutan is the country with a population of just 7.7 lakhs and it had limited its number of infections to just 7 till 10th May with no death. Bhutanese government actively worked in quarantining of at least 14 days to those who have been tested positive or contact persons of those infected and working on strengthening the existing infrastructure. Bhutan sealed its borders with India and suspended the entry of all foreign arrivals. Bhutan limits the number of infections as a result of heavy contact tracing and extensive testing much higher than in other South Asian countries. Further, the country on March 22, decided to shut down completely.

\section{Endnotes}

1. TTiezzi, S., Putz, C., and Panda, A., 2020. COVID-19 In Asia: A Country-By-Country Guide. [online] Thediplomat.com. Available at: <https://thediplomat.com/2020/04/covid-19-in-asia-a-country-by-country-guide/> [Accessed 13 May 2020].

2. Basu D, Srivastava P. In South Asia, Lanka Leads and India Lags in Infrastructure, Medical Response to COVID-19 [Internet]. The Wire. 2020 [cited 20 May 2020]. Available from: https://thewire.in/health/in-south-asia-lanka-leadsand-india-lags-in-infrastructure-medical-response-to-covid-19

3. BChattacharjee D. South Asia and Covid-19: The Present Challenges and Upcoming Trends - Indian Council of World Affairs (Government of India) [Internet]. Icwa.in. 2020 [cited 20 May 2020]. Available from: https://www.icwa.in/show_content.php?lang=1\&level=3\&ls id=4701\&lid=3528

4. 1Fliegauf E, Ayres A. Coronavirus in South Asia, April 30, 2020: India, Pakistan, and Bangladesh Begin Easing Restrictions [Internet]. Council on Foreign Relations. 2020 [cited 20 May 2020]. Available from: https://www.cfr.org/blog/coronavirus-south-asia-april-30-2020-india-pakistan-and-bangladesh-begin-easing$\underline{\text { restrictions }}$

5. 9. Wardak M. The COVID19 reality of Afghanistan | ORF [Internet]. ORF. 2020 [cited 20 May 2020]. Available from: https://www.orfonline.org/expert-speak/the-covid-19-reality-of-afghanistan-64847/

6. What Explains Bhutan's Success Battling COVID-19? [Internet]. Thediplomat.com. 2020 [cited 20 May 2020]. Available from: https://thediplomat.com/2020/05/what-explains-bhutans-success-battling-covid-19/

7. Notice Regarding Temporary Shutdown of Visa Services [Internet]. Nepalimmigration.gov.np. 2020 [cited 20 May 2020]. Available from: http://www.nepalimmigration.gov.np/post/notice-regarding-temporary-shutdown-of-visa$\underline{\text { services-2 }}$

8. Khadka A. How Nepal has tried to tackle the Covid19 pandemic | ORF [Internet]. ORF. 2020 [cited 21 May 2020 ]. Available from: https://www.orfonline.org/expert-speak/how-nepal-has-tried-to-tackle-the-covid19-pandemic-66173/

\section{$\underline{\text { Western Asia }}$}




\section{United Arab Emirates}

UAE has a population of 9.8 million people however; 18,198 cases and 198 deaths on the $10^{\text {th }}$ of May. It mandates travel bans and suspended the scheduled flights. Rapid Covid-19 tests have been performed before departure. It implemented quarantine measures and canceled the public, religious or social events, and restricted one member per family to go out for essential buying. As of 5th May, the UAE has conducted 1.2 million coronavirus tests by the $10^{\text {th }}$ of May with a huge capacity of testing more than lakh people per million. The country tests for free for symptomatic people, elders, women, and those with chronic conditions across the UAE. To manage the pandemic load, an AI company offered free bots to help healthcare. Even the Dubai World Trade Centre had been converted to Field hospitals to treat 3000 patients of Covid-19 as on $15^{\text {th }}$ April.

\section{Iraq}

Iraq is the second most populated country in West Asia with 40 million people. Iraq closed its borders with Iran in mid-February to control the virus spread. Iraq's response to the pandemic in early March was through closing borders, banned public gatherings, and the nationwide curfew had been only partially enforced. Iraq has comparatively lower cases accounts to 2679 as of $10^{\text {th }}$ May, however, it is about to witness the exponential growth in COVID-19 cases. Further a country-wide lockdown was later imposed in mid-March and closed borders with some Asian and European countries.

\section{Saudi Arabia}

Saudi Arabia has a population of 34 million and it has a total of 39,048 which is largest across western Asia as on the $10^{\text {th }}$ of May. The country's major cities were under lockdown as of $6^{\text {th }}$ April. All the international flights were suspended, restricted public gatherings and closures of religious places had been suspended with shutting down all the economic activities except essentials. Testing capacity is also low just 12000 per million.

\section{Israel}

Israel being a similar country like UAE in terms of the population just 8.6 million also has similar infected cases. The country has 16458 confirmed cases with 248 deaths. The country took late measures by restricted movements; it allowed all the Israelis to enter Israel with self-isolation of 14-day quarantine. Moreover closed the public places and cancelled events as of $15^{\text {th }}$ May for more than 50 people. To strengthen the health sector capacity and civil needs, it funded a large amount.

\section{Turkey}


Turkey being the largest populated country in Western Asia has a very high pandemic load with 1, 37,000 positive cases, and closer to 4,000 deaths as on the $10^{\text {th }}$ of May. By early April, the country had the highest increase in Covid-19 cases as social distancing and testing was only confined to travelers from abroad. It did not manage to have kept the number low due to its huge population and mismanaged health system. Initially it banned travelers entering Turkey from virus-affected countries are taken under quarantine for 14 days, irrespective of nationality. Turkey applied curfews and quarantined people all over since the end of March. Intercity travel was also prohibited. All the public places were closed and public events were canceled. As of $6^{\text {th }}$ April, 5 free protective masks per week were distributed via postal delivery and made it compulsory for all in public places. Citizen arrived were also kept under quarantine in special facilities for 14 days. The country-wide test centers have increased with rapid diagnostic kits and raised the capacity to 10,000 or more tests a day. Being a highly populated country it has done the highest tests however the per million testings is much lower to just 15000 per million people. Home healthcare was introduced for senior citizens and strengthen health infrastructure by constructed new hospitals. 5000 teams of 2-3 health workers were authorized to do contact tracing. However, the country now has reopened some services with strict protocols.

\section{Georgia}

Georgia being is a developed country has a population of just 3.9 million and still has a pandemic load. It has 635 cases and just 10 deaths. Most of the cases have been found in the Capital city. The country at the end of January closed schools and Universities and create awareness of hygiene and social distancing among people through mass media. Further closed borders and canceled flights from high containment countries. Later on $21^{\text {st }}$ April, the country went on complete lockdown and closed all the non-essential services to maintain social distancing and closed all public places and converted the high-class hotels into quarantine zones for travelers. The country imposed fines for violating the emergency rules up to the US \$940 for individuals and thrice of the amount for legal entities.

\section{Syria}

Syria with a population accounts to 17.5 million has the lowest infected cases across Western Asia. As of 22 March the first positive case came in and as of 17 April, 38 cases have been confirmed in parts of Syria except for north Syria which has now stood only at 47 as of $10^{\text {th }}$ of May. The mitigation measures by the country were the closure of schools, some public places, banned religious gatherings, and imposing night curfews. Cross border restrictions between Turkey and Syria. At the border, infection prevention and control (IPC) measures taken place. By the end of April, for Syria, increasing lab testing remains a priority and training of laboratory technicians and rapid response teams (RRTs). Prevention \& preparedness for potential cases have been done through early detection and rapid response to COVID-19.

\section{Yemen}


Yemen has a population of 29.8 million and its first COVID-19 case was confirmed on 10 April. Since then as of the $10^{\text {th }}$ of May it has a fewer number of cases accounts to 34 and 7 deaths. However, Yemen took very early mitigation measures in March before a case and had instituted several mitigation measures against the spread of COVID-19, including the closure of borders. Further, the country's national COVID-19 Plan was prioritizing case identification through contact tracing; risk communication and disease surveillance, and treatment by maintaining essential health services. However, Yemen has a weaker healthcare system and the country us at a high risk of an increasing number of cases.

\section{Jordan}

Jordan has more than 10 million people living in the country maintained its cases below 1000. Iraq's fear of Covid-19 spread made it happen as, in early March, the measures of banning land and air travel with Iraq and the country has been screening people entering the country's borders and airports. It implemented mandatory testing that now only check the temperature but check chest and throat examinations along with it. In mid-march just after its few cases, imposed a tight lockdown in the country, and arrivals took strict 14 days quarantine measures. Thus, it has just 522 confirmed cases and 9 deaths as a result of most early actions and quicker stringent measures taken by the government than other countries and save its healthcare. All public meetings got canceled, a strict curfew announced every day at 6:00 p.m. with a siren echo around the country until 10 a.m. the next morning was imposed. Social distancing was done with requisite measures, even a walk to local stores was not allowed during the day, and vehicles were also prohibited. Violators were imposed with a fine of about $\$ 140$, which doubles for a second offense and can lead to imprisonment.

\section{Lebanon}

Lebanon has just 6.8 million of population and also managed to contain the spread. The country has been under lockdown since mid-March and now has infected 845 people and killed 26 as of $10^{\text {th }}$ May. The country closed the entry in borders from airports, seaports, and land entrances from March. However, it has now started operating at someplace with far low capacity. But the country is in fear of another wave.

\section{Endnotes}

1. Siradze E. Georgia goes all out in a fight against Covid19 | ORF [Internet]. ORF. 2020 [cited 22 May 2020 ]. Available from: https://www.orfonline.org/expert-speak/georgia-goes-all-out-in-fight-against-covid19-64651/

2. IOM Yemen: COVID-19 Response Update, 19 April - 02 May 2020 - Yemen [Internet]. ReliefWeb. 2020 [cited 22 May 2020]. Available from: https://reliefweb.int/report/yemen/iom-yemen-covid-19-response-update-19-april-02$\underline{\text { may-2020 }}$

3. Reliefweb.int. 2020 [cited 23 May 2020]. Available https://reliefweb.int/sites/reliefweb.int/files/resources/nw_syria_situation_report12_17042020.pdf 
4. Syrian Arab Republic: COVID-19 Response Update No. 03 - 13 May 2020 - Syrian Arab Republic [Internet]. ReliefWeb. 2020 [cited 23 May 2020]. Available from: https://reliefweb.int/report/syrian-arab-republic/syrian-arabrepublic-covid-19-response-update-no-03-13-may-2020

5. MITIGATING THE IMPACT OF COVID-19 IN IRAQ - EPIC - Enabling Peace in Iraq Center [Internet]. EPIC Enabling Peace in Iraq Center. 2020 [cited 24 May 2020]. Available from: https://enablingpeace.org/mitigating-theimpact-of-covid-19-in-iraq/

6. COVID-19 crisis response in MENA countries [Internet]. OECD. 2020 [cited 23 May 2020]. Available from: http://www.oecd.org/coronavirus/policy-responses/covid-19-crisis-response-in-mena-countries-4b366396/

7. COVID-19: Perfect Storm for Israel, Iraq, Lebanon, and Jordan | Manohar Parrikar Institute for Defence Studies and Analyses [Internet]. Idsa.in. 2020 [cited 24 May 2020]. Available from: https://idsa.in/idsacomments/covid-19-israeliraqi-lebanon-jordan-adil-jatin\#footnote19_njssdt9

8. Tadros A. Drastic, early action seems to keep a lid on Jordan's COVID-19 outbreak [Internet]. Cbsnews.com. 2020 [cited 24 May 2020]. Available from: https://www.cbsnews.com/news/coronavirus-in-jordan-seemingly-kept-incheck-by-drastic-early-lockdown-measures/

9. Lebanon fears the second coronavirus wave as new infections surge | The Guardian. theguardian.pe.ca. 2020 [cited 24 May 2020]. Available from: https://www.theguardian.pe.ca/news/world/lebanon-fears-second-coronavirus-wave-asnew-infections-surge-448228/

10. Worldometers. (Coronavirus Update (Live): 5,481,115 Cases and 346,071 Deaths from COVID-19 Virus Pandemic Worldometer [Internet]. Worldometers.info. $2020 \quad\left[10^{\text {th }} \quad\right.$ May 2020]. Available from: https://www.worldometers.info/coronavirus/) 